\title{
Population Study of Diabrotica speciosa (Ger.) (Coleoptera: Chrysomelidae) in Fall / Winter Season
}

\author{
Estudo Populacional de Diabrotica speciosa (Ger.) (Coleoptera: Chrysomelidae) \\ no Outono / Inverno
}

Maurício Ursi Ventura ${ }^{1}$ Marcos Roberto Gomes ${ }^{2}$

\begin{abstract}
Estudo populacional de D. speciosa nas culturas de outono / inverno, foi conduzdo. Larvas foram monitorados, nas culturas do milho (Zea mays L.), trigo (Triticum aestivum L.) e aveia preta (Avena strigosa Schreb.) e adultos em soja (Glycine max (L.) Mill., milho, feijão (Phaseolus vulgaris L.), trigo e aveia preta de 23/03/2001 a 24/08/2001. A soja, milho, feijão, trigo e aveia preta foram semeadas em 28/12/2001, 9/ 02/2001, 2/03/2001, 26/04/2001 e 11/05/2001, respectivamente. Milho e feijão foram cultivados em "safrinha". Adultos foram coletados durante quase todo o período de amostragens. Os maiores picos populacionais ocorreram no trigo, em 3/08/ 2001, que coincidiu com o período de florescimento. A dinâmica populacional de machos e fêmeas foi similar no feijão e na soja. Na cultura do milho, fêmeas predominaram 30 dias após a emergência (dae) (antes não foram detectados) até cerca de 45 dae. Machos ocorreram principalmente durante o período de florescimento. Populações similares de machos e fêmeas foram verificadas no trigo e aveia preta. Maior pico de larvas ocorreu em raízes de milho. O milho safrinha foi introduzido há alguns anos e provavelmente é o fator que determina as crescentes populações da praga relatadas durante todo o ano. Possíveis aplicações dos resultados deste estudo são discutidas.
\end{abstract}

Palavras-chave: Insecta, plantas hospedeiras, fenologia, safrinha, amostragens.

\section{ABSTRACT}

Population studies of D. speciosa on fall / winter crops were conducted. Larvae were monitored on maize (Zea mays L.), wheat (Triticum aestivum L.) and black oats (Avena strigosa Schreb.) and beetles on soybeans (Glycine max (L.)
Mill., maize, common beans (Phaseolus vulgaris L.), wheat and black oats from March 23, 2001 to August 24, 2001. Soybean, maize, common beans, wheat and oats were sown on December 28, 2000; February 9, 2001; March 2, 2001; April 26, 2001 and May 11, 2001, respectively. Maize and common beans were grown on latter growing season. Adult beetles of $\boldsymbol{D}$. speciosa were collected throughout the sampling period. Greatest beetles population peak occurred on wheat in August 3, 2001 which coincided with flowering period. Population dynamics of males and females was similar on common beans and soybeans. Females on maize predominate mostly after the first 30 days after the plant emergence (dae) (before were not detected) until about 45 dae. Males appeared to predominate during the flowering period. Similar population dynamics of males and females were found on wheat and black oats. Greatest peak of larvae occurred on maize roots. The growing season corn farm system was recently introduced, what probably explains the reports of increasing populations of adults during almost the whole year. Probable applications of the results are discussed.

Key words: Insecta, host plants, phenology, latter growing season, samples.

The leaf beetle Diabrotica speciosa is an important pest widespread in Latin America which damages plants of several botanical families (KRYSAN, 1986). A series of host plants were listed by SILVA et al. (1968) when about 80 bibliographic citations were available. Larvae are root pests on grasses including among others mayze (Zea mays L.), wheat (Triticum aestivum L.) and potato (Solanum tuberosum L.) and oat (Avena spp.) (BERTELS et al., 1956).

${ }^{1}$ Professor Adjunto, Doutor, Departamento de Agronomia, Centro de Ciências Agrárias (CCA), Universidade Estadual de Londrina (UEL), CP 6001, 86051-970, Londrina, PR. E-mail: mventura@uel.br. Autor para correspondência.

${ }^{2}$ Acadêmico de graduação em agronomia da UEL. 
Population dynamics studies are basic for Integrated Pest Management Programs development (PANIZZI, 1997; HEIN et al. 1988). Specifically for $\boldsymbol{D}$. speciosa, these researches are scarce and almost exclusively restricted to adults (e.g. HOHMANN \& CARVALHO, 1989). Rare studies concerned with larvae are reported (e.g. BIANCO, 1991). Beetles population peaks were reported in February in Paraná during three years of sampling (HOHMAN \& CARVALHO, 1989). In recent years, rising populations of $\boldsymbol{D}$. speciosa have been reported on several crops during almost the entire year (ROBERTO et al., 2001). One probable explanation for beetle increasing populations include the introduction of the latter growing season maize but studies were not carried out to confirm this hypothesis.

Semiochemicals [volatile attractant $(1,4-$ dimethoxybenzene) and feeding stimulant and arrestant (cucurbitacin)] were proposed as a suitable tool for D. speciosa management (VENTURA et al., 1996; VENTURA et al., 2000). However, basic information are necessary to apply successful this tactics: depending on population peaks, control tactics could be used in suitable seasons.

Hence, we studied the population dynamics of D. speciosa on fall / winter seasons. Our hypothesis is that successive host plant availability (maize and afterwards wheat) provide suitable conditions for continuous insect development, which would be changing peaks of adults in the field. In addition, knowledge from field sampling could provide information to manage successfully the pest using semiochemicals. So, larvae were monitored on maize, wheat and black oats (Avena strigosa Schreb.) and beetles on soybeans (Glycine max L.) Mill., maize, common beans (Phaseolus vulgaris L.), wheat and black oats.

Once a week from March 23, 2001 to August

24, 2001, larvae and adults of $\boldsymbol{D}$. speciosa were monitored on crops in the Universidade Estadual de Londrina School Farm experimental fields, in Londrina, PR, Brazil (latitude 23 $19^{\prime}$ S, longitude $51^{\circ} 12^{\prime} \mathrm{W}$ ). The larvae sampling were carried out on maize cv. AS 32 (Zea mays L.), wheat (Triticum aestivum L.) cv. Alcover and black oats cv. IAPAR 61. Adults assessment were achieved on maize, soybeans cv. BR 48, common beans cv. IAPAR 59, wheat and black oats. Common beans and maize were grown on latter growing season. Soybean, maize, common beans, wheat and oats were sown on December 28, 2000; February 9, 2001; March 2, 2001; April 26, 2001 and May 11, 2001, respectively. A selected area of $5000 \mathrm{~m}^{2}$ was used for each crop. Assessments were initiated when beetles were found on maize.
For larvae monitoring, nine samples $\left(8000 \mathrm{~cm}^{3}\right.$ of soil) were randomized collected per field. The unit of the samples consisted of a cube (20 X $20 \mathrm{X}$ $20 \mathrm{~cm})$. The bases of the corn plant coincided with the center of one square of the cube. For wheat and black oats, crop line (means 12.7 and 16 plants per sample for wheat and black oats, respectively) divided the top square in two equals triangles. Larvae were separated from the soil though a sieve (1.5mm mesh). Adult monitoring was achieved from sweep net (50 samples per field at random). Insects were placed in cages and returned to laboratory where the beetles were identified to species and sexed (WHITE, 1977).

Adult beetles of $\boldsymbol{D}$. speciosa were collected during the whole period of samples (Figure 1). Greatest insect population peak occurred on wheat on August 3, 2001 which coincided with flowering period. Beetles of the genus Diabrotica are formerly pollen feeders which expanded their feeding habits to other plant parts (leaves, stems, flowers) (METCALF \& LAMPMAN, 1989).

Population dynamic of males and females was similar on common beans and soybeans which were not sampled from the onset the crop cycle.

Females on maize predominate (means 3.5 females per male) mostly after the first 30 days after the plant emergence (dae) (before were not detected) until about 45 dae. Hence, adult control measures (including kairomones) to avoid larvae damage, must be applied in this period. Since females of $\boldsymbol{D}$. undecimpuctata howardi are reported to be more responsive to cucurbitacins after mating (TALLAMY \& HALAWEISH, 1993), further investigation could check effective control using this semiochemical.

Males appeared to predominate (3.3 males per female) during the flowering period (May 24, 2001) probably due to pollen feeding habit. Adult beetles of D. barberi Smith \& Lawrence and $\boldsymbol{D}$. virgifera virgifera LeConte are attracted by volatile from maize silk (HIBBARD et al., 1997; HAMMACK, 1997).

Similar population dynamics of males and females were found on wheat and black oats. Hence no predominance of any sex occurred according to plant phenology.

Larvae: Greatest peak of larvae occurred on maize roots (Fig. 2). Maize is a preferential host plant of $\boldsymbol{D}$. speciosa due to coevolved relationships between the insect and the plant (KRYSAM, 1986). D. speciosa also adapted to introduced plants (wheat and black oats). On wheat, damages of $\boldsymbol{D}$. speciosa larvae are reported (GASSEN, 1989). However we did not find records of larvae of $\boldsymbol{D}$. speciosa on oat roots. $\boldsymbol{D}$. speciosa expanded its host range for black oats which 


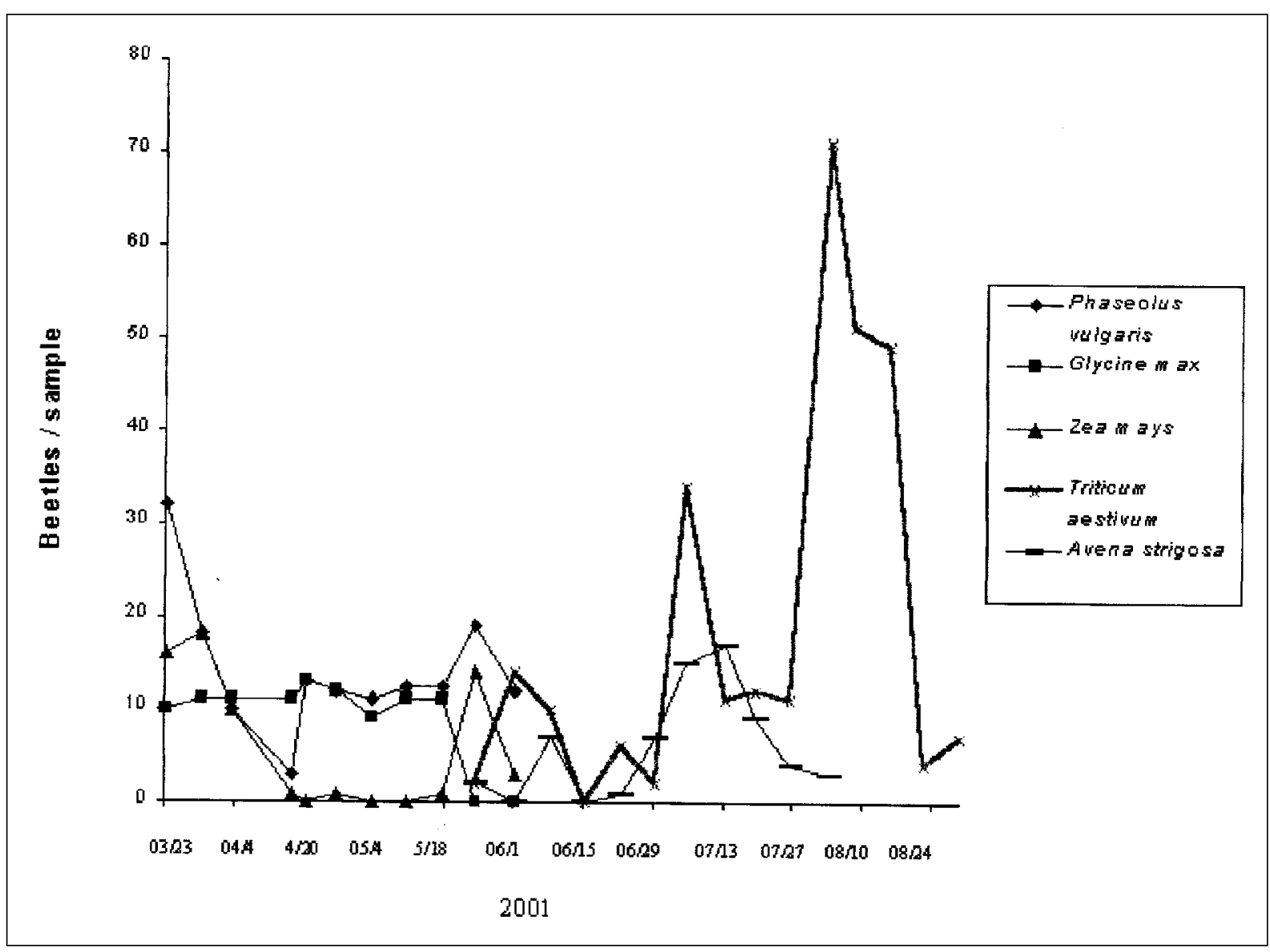

Figura 1 - Population dynamics of D. speciosa on host plants, common beans (Phaseolus vulgaris), soybeans (Glycine max), mayze (Zea mays), wheat (Triticum aestivum) and black oats (Avena strigosa). Londrina, 2001.

is largely used as cover crop rotated with soybeans. Host range expansion is an ordinary strategy in insectpests. In Illinois and Indiana States (USA), D. virgifera virgifera was reported ovipositing on soybean making crop rotation ineffective on its management (CHANDLER, 1998).

Adults peak, mostly of females, corresponded to larvae peaks about 30 days afterwards on maize and wheat fields (Figure1 and 2). This corroborates AVILA \& PARRA (2002) data of developing period of $\boldsymbol{D}$. speciosa (about 25 days; at means $25^{\circ} \mathrm{C}$ ). On maize, crop in which semiochemicals traps and baits have been proposed for controling ovipositing females (CHANDLER \& SUTTER, 1997; CHANDLER, 1998; VENTURA et al., 2000) protection period probably must last from 30 to 50 days after plant emergence in latter growing season maize.

Low densities of $\boldsymbol{D}$. speciosa larvae damages seriously maize on spring / summer season plantings (MARQUES et al., 1999). Economic damage level of larvae on latter growing season maize is not studied. Our results revealed the necessity of further investigation on this subject due to relatively high larvae population on maize roots.

Studies achieved before introduction of the latter growing season maize (1982/83, 83/84 e 84/85) revealed beetles peaks mostly in February (from larvae from spring / summer season maize) (HOHMAN \& CARVALHO, 1989) and low densities in the remainder months. The introduction of this new farming system provided suitable conditions for $\boldsymbol{D}$. speciosa larvae development in an extended period during the year and probably explains the increasing reported populations and damages (ROBERTO et al., 2001).

Farmers cited $D$. speciosa adults occurring during several months in the region studied in contrast to previous literature records of adults peak in February / March. Females beetles of D. speciosa were detected from 30 to 45 days after maize emergence (latter season planting). Greatest peak of larvae were found on latter season maize (recently introduced in the farm system) and this explains adults peak in 


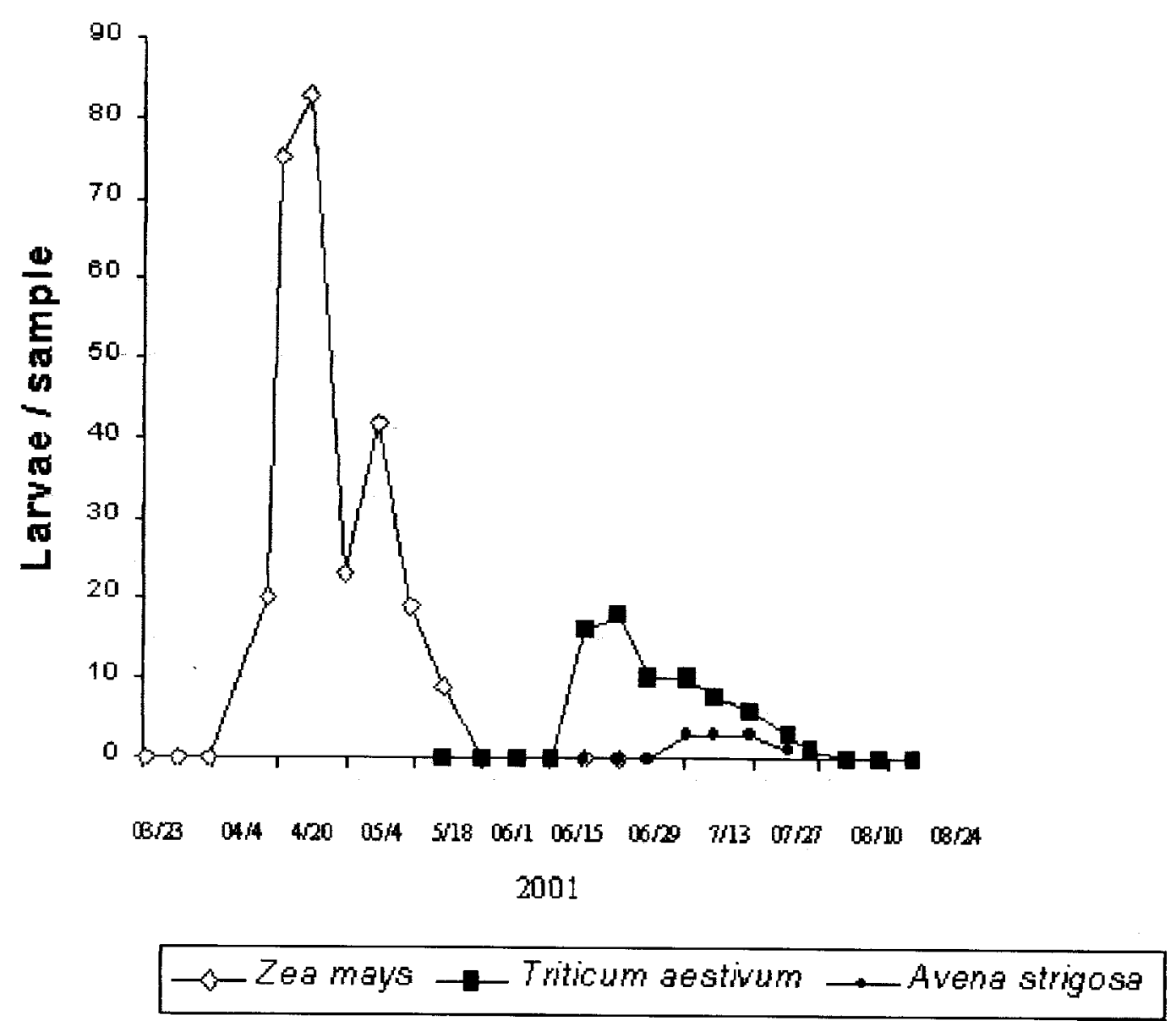

Figura 2 - Population dynamics of D. speciosa larvae on roots of host plants, mayze (Zea mays), wheat (Triticum aestivum) and black oats (Avena strigosa). Londrina, 2001.

seasons that were not recorded before. Larvae were found developing on black oats roots.

\section{REFERENCES}

AVILA, C.J.; PARRA, J.R.P. Desenvolvimento de Diabrotica speciosa (Germar) (Coleoptera: chrysomelidae) em diferentes hospedeiros. Ciência Rural, Santa Maria, v.32, p.739-743, 2002.

BERTELS, M.A. Entomologia agrícola sul-brasileira. Brasília: SIA, 1956. 458p.

BIANCO, R. Pragas e seu controle. In: IAPAR: Cultura do milho. Londrina: Iapar, 271p, 1991, p.187-221.

CHANDLER, L.D. Comparison of insecticide-bait aerial application methods for management of corn rootworm (Coleoptera: Chrysomelidae). Southwestern Entomol, Dallas, v.23, p.147-159, 1998.

CHANDLER, L.D.; SUTTER, G.R. High clearance sprayer methods for application of corn rootworm
(Coleoptera: Crysomelidae) semiochemical-based baits. Southwestern Entomol, Dallas, v.22, p.167-178, 1997.

GASSEN, D.N. Insetos subterrâneos prejudiciais às culturas no sul do Brasil. Passo Fundo: EMBRAPA-CNPT, 1989, 72p. (Documentos, 13).

HAMMACK, L. Attractiveness of synthetic corn volatiles to feral northern ans western corn rootworm beetles (Coleoptera: Chrysomelidae). Environ Entomol, Lanham, v.26, p.311-317, 1997.

HIBBARD, B.E. et al. Electroantennogram-active components of maize silk for adults of the western corn rootworm (Coleoptera: Chrysomelidae). Environ Entomol, Lanham, v.26, p.287-295, 1997.

HEIN, G.L. et al. Adult northern and westerm corn rootworm (Coleoptera: Chrysomelidae) population dynamics and oviposition. J Kansas Entomol Soc Lawrence, v.6, p.214-223, 1988. 
HOHMANN, C.L.; CARVALHO, S.M. Pragas e seu controle. In: IAPAR. O Feijão no Paraná. Londrina : Iapar, 1989. p.217-246.

KRYSAN, J.L. Introduction: biology, distribuition, and identification of pest Diabrotica. In: KRYSAN, J.L.; MILLER, T.A. (eds.). Methods for study of pest Diabrotica. New York : Spring-Verlag, 1986. p.1-24

MARQUES, G.B.C. et al. Danos causados por larvas de Diabrotica speciosa (Coleoptera: Chrysomelidae) em milho. Pesq Agropec Bras, Brasília, v.34, p.1983-1986, 1999.

METCALF, RL.; LAMPMAN, R.L. Chemical ecology of Diabroticites and Cucurtitaceae. Experientia, Bassel, v.45, p.240-247, 1989.

PANIZZI AR. Wild hosts of pentatomids: Ecological significance and role in their pest status on crops. Annu Rev Entomol, Palo Alto, v.42, p.99-122, 1997.

ROBERTO, S.R. et al. Diabrotica speciosa (Ger.) (Coleoptera: Chrysomelidae): New pest in table grape orchards. Neotrop Entomol
Londrina, v.30, p.721-722, 2001.

SILVA, A.G.A. et al. Quarto catálogo dos insetos que vivem nas plantas do Brasil. Seus parasitos e predadores. Rio de Janeiro : Ministério da Agricultura, 1968. 622p.

TALLAMY, D.W.; HALAWEISH, F.T. Effects of age, reproductive activity, sex, and prior exposure on sensitivity to cucurbitacins in southern corn rootworm (Coleoptera: Chrysomelidae). Environ Entomol, Lanham, v.22, p.925932, 1993.

VENTURA, M.U. et al. An attractive trap to capture Diabrotica speciosa and Cerotoma arcuata tingomariana. Neotrop Entomol, Londrina, v.25, p.529-535, 1996.

VENTURA, M.U. et al. Responses of Daibrotica speciosa and Cerotoma arcuata tingomariana to volatile attractants. Florida Entomol, Lutz, v.83, p.403-410, 2000.

WHITE, W. Sexual characters of species of Diabrotica (Chrysomelidae: Coleoptera). Ann Entomol Soc Am, Lanham, v.70, p.168, 1977. 